\title{
Composting and co-composting of coffee husk and pulp with source-separated municipal solid waste: a breakthrough in valorization of coffee waste
}

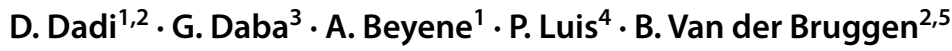

Received: 3 July 2018 / Accepted: 12 March 2019 / Published online: 19 March 2019

(c) The Author(s) 2019

\begin{abstract}
Purpose In this study, the composting and co-composting potential of coffee husk and pulp with source-separated municipal solid waste (SSMSW) was investigated.

Methods Coffee husk and pulp were mixed independently with SSMSW in different proportions $(0,33,50$ and $100 \%)$, and composted in triplicates with a total of 24 composting piles for 3 months. From each compost type, different physicochemical parameters were analyzed. In addition, the seed germination, growth and fresh head weight yield of each compost type were investigated on each matured compost type using cabbage seed (Brassica oleracea).

Results The results indicate that the two coffee by-products can be composted alone or co-composted with SSMSW yielding very mature and stable compost. The results indicated that the addition of 1/4th of local soil (wt/wt) on C8 compost type yields the optimum fresh head weight of the cabbage among all field experiments. In addition, when C8 compost type is mixed with local soil in 3:1 ratio, it could yield an optimum fresh head weight of the cabbage $(572 \pm 10 \mathrm{~g} / \mathrm{kg}$ of compost). This could be due to the relatively higher concentration of total nitrogen in the $\mathrm{C} 8$ compost sample.

Conclusions Generally, the final compost can be served for unrestricted type of agricultural purposes. Thus, co-composing of coffee husk and pulp with SSMSW can alleviate the multidimensional problems of rural and urban dwellers.
\end{abstract}

Keywords Coffee husk $\cdot$ Valorization $\cdot$ Co-composting $\cdot$ Maturity $\cdot$ Compost quality $\cdot$ Productivity

\section{Introduction}

D. Dadi

dessalegndadiolani@gmail.com; dessalegn.dadi@ju.edu.et

1 Department of Environmental Health Sciences and Technology, Jimma University, P.O. Box 378, Jimma, Ethiopia

2 Bio- and Chemical Systems Technology, Reactor Engineering and Safety Department of Chemical Engineering, Leuven Chem \& Tech, KU Leuven, Celestijnenlaan 200F, Box 2424, 3001 Louvain, Belgium

3 Department of Horticulture and Plant Sciences, College of Agriculture and Veterinary Medicine, Jimma University, P.O. Box 307, Jimma, Ethiopia

4 Materials and Process Engineering (iMMC-IMAP), Université catholique de Louvain, Place Sainte Barbe 2, 1348 Louvain-la-Neuve, Belgium

5 Faculty of Engineering and the Built Environment, Tshwane University of Technology, Private Bag X680, Pretoria 0001, South Africa
Production and processing of coffee in Ethiopia has a crucial role in the economy of the country since $65 \%$ of the total export is from coffee. Approximately, 15 million people (20\% of the population) are directly involved in coffee industry for their livelihood in the country (Wiersum et al. 2008). Coffee-processing industries are causing environmental hazards due to large-scale disposal of coffee pulp, husk and effluents into arable land and surface water (Preethu et al. 2007). The environmental impacts of coffee production and processing are vast, with large quantities of solid and liquid wastes generated globally (Hue et al. 2006). Over 10 million tonnes of solid residues are generated yearly from the coffee agro-industry worldwide, along with large amount of wastewater and cultivation residues (Echeverria and Nuti 2017).

Even though coffee husk and pulp are rich in organic matter and nutrients, they also contain compounds such as caffeine, tannins and polyphenols (Franca and Oliveira 2009). 
Due to the presence of the latter compounds, the organic solid residues are toxic in nature (Pandey et al. 2000b). In this regard, the studies of Franca and Oliveira (2009) indicated that coffee husk comprised of dry outer skin, pulp and parchment is probably the major residue from the handling and processing of coffee; since for every $\mathrm{kg}$ of coffee beans produced, approximately $1 \mathrm{~kg}$ of husk is generated during dry processing. Similarly, Zoca et al. (2014) reported that since $50 \%$ of the harvested coffee is husk, it is important to consider that these by-products can contribute to environmental problems if not disposed of properly. Thus, there is a need to find alternative uses for these residues.

The life cycle analysis of coffee conducted by Salomone (2003) confirmed that processing of coffee highly contributes to cause environmental impacts. In addition, Preethu et al. (2007) indicated that the presence of phytotoxic substances and organic acids in coffee by-products is affecting the soil, water quality and restricts the crop growth. However, coffee waste contains a high concentration of biodegradable organic compounds and minerals of plant origin, which can be utilized by composting with other organic materials.

Getahun et al. (2012a) reported that in Jimma town, Ethiopia, a considerable amount of waste ends up in open dumps without any sorting or treatment and is exposed to human and animal scavengers. Lemma and Tekilu (2014) reported that organic matter constitutes $92.5 \%$ of the municipal solid waste generated in Hosanna, Ethiopia, out of which 'chat' stalk constitutes 3\%, which causes a major problem in logging the drainage and tipping additional pollution. The harvested green khat plant (received moist) is traditionally packaged as bundles of young shoots that are wrapped in the leaf of the false-banana plant to help maintain product freshness (Geisshüsler and Brenneisen 1987). In Ethiopia, almost 10 million people are dependent on Ensete (Ensete ventricosum) also known as the false banana for different purposes (Pijls et al. 1995). The use of the leaves of false banana to retain khat's moistness and freshness for longterm storage is common in Ethiopia, where khat chewing is commonly practiced. However, it is afterward disposed into the local environment. Thus, sustainable solutions must be sought for its better management.

The use of organic compost in agriculture is a practice that brings many advantages, avoiding environmental contamination and nutrients immobilization, and is a source of organic matter in the soil (De Rezende et al. 2012). The treatment of coffee by-products through oxygen-driven biological methods would serve a dual purpose, i.e., fertilizer production and environmental protection (Murthy and Naidu 2012). In this regard, Preethu et al. (2007) reported that treatment of coffee waste by composting reduces the severe damage that the application of immature compost to the soil would cause and allows a complete conservation of the residual energy stored in the organic material. Composting is a spontaneous biological decomposition process of organic materials in a predominantly aerobic environment (Bernal et al. 2009).

The detailed review conducted by Bernal et al. (2009) reported that while composting occurs naturally, efficient composting requires the control of several factors (bulk density, porosity, particle size, nutrient content, $C / N$ ratio, temperature, $\mathrm{pH}$, moisture and oxygen supply) to avoid nuisance problems such as odor, dust and also for obtaining an agricultural product with high quality. In this regard, Yusuf (2008) indicated that composts can vary because of several reasons.

Before applying compost to land, its maturity as well as its stability has be evaluated first since it may seriously affect the plants growth due to the presence of pathogenic microorganisms and nutrients which can cause disturbance of the soil in where it is used (Gazi et al. 2007). Getahun et al. (2012b) reported that for the safe use of compost in agriculture, the production of quality compost, which is mature and containing low concentration of metals and salt content, is essential. The detailed review conducted by Bernal et al. (2009) also indicated that the major requirement of compost to be safely used in soil is a high degree of stability or maturity, which implies a stable organic matter content and the absence of phytotoxic compounds and plant or animal pathogens. The same study also indicated that before the application of compost produced from MSW, the heavy metal concentration in the compost as well as the reference plant growth should be assessed first.

Recent case studies (Franca and Oliveira 2009; Kassa et al. 2011; De Rezende et al. 2012; Shemekite et al. 2014; Degefe et al. 2016) reported composting of coffee husk with cow dung, fruits/vegetables, effective microorganisms and Khat (Catha edulis). However, no research was carried out to investigate the composting and co-composting of coffee husk and pulp with source-separated municipal solid waste including the leaves of false banana (Ensete ventricosum), fruits, vegetables, khat/Catha edulis and soft dry wood at different proportions. Therefore, in this study, the composting and co-composting potential of coffee husk and pulp with source-separated municipal solid waste is carried in addition to the analysis of heavy metal concentrations of matured compost samples, and seed germination and growth tests on composted samples. Further, biochar application on composted samples was studied to verify the productivity/ yield of the fresh head weight of the cabbage.

\section{Methods and materials}

\section{Coffee waste collection}

The two coffee by-products, namely pulp and husk, were obtained from wet and dry coffee-processing plants, 
respectively, in Yebbu town, Manna district, Jimma zone, Ethiopia. The composting study was conducted at the Abdi Jimma community-based waste management and composting micro-enterprise, Jimma town, Ethiopia. The municipal solid waste was collected from residential houses of Jimma town. The soft dry wood was collected from wood microenterprises found in Jimma town. To increase particle size, maintain an adequate porosity and aerobic conditions in compost piles, soft dry wood was used as a bulking agent. The collected coffee husk and pulp were stored in a dry place until composting has started. The municipal solid waste was sorted out and chopped. The biochar samples, which were prepared from the different coffee waste fractions, and, which were used for the germination, growth and yield productivity test of matured compost samples, were obtained from Hasselt University, Department of Applied and Analytical Chemistry, Belgium.

\section{Experimental setup of the composting process}

Twenty-four heaps were composted using the aerobic windrow composting type, subjected to manual turning. The compost had a volume of $1 \mathrm{~m}^{3}$. The composting activity was conducted in triplicates and has the volume ratios as indicated in Table 1.

The composting activity was conducted for 3 months. The composting was undertaken in an open house with cemented floor and under a shade. The compost heaps were shielded with perforated HDPE plastic to avoid heat emission and to prevent the compost from drying. While turning the compost, the piles were watered after checking the moisture content of the samples. Gajalakshmi and Abbasi (2008) indicated that the optimum water content for composting varies with the waste to be composted, but generally the mixture should be at $50-60 \%$. The compost was turned 2-3 times a week during the first two active months of composting, while the frequency of turning was reduced to only once a week afterward.

\section{Determination of physicochemical parameters}

The samples from each experimental composting pile were collected weekly to monitor the changes in physicochemical parameters ( $\mathrm{pH}$, electrical conductivity, organic carbon, available phosphorous and total nitrogen). All the samples were analyzed in triplicate, and the mean results were reported. However, the temperature of the piles was recorded on a daily basis for 90 days ( 12 weeks) and the weekly average result was reported. To obtain a homogenous and representative sample of the entire heap, samples were taken from each pile from all sides of the pile and thoroughly mixed together. Afterward, the sample was ground by using a pestle and mortar to pass through a sieve (Dadi et al. 2012). Glass thermometer is used to measure the temperature onsite. The $\mathrm{pH}$ and EC were measured using a Hach multi-meter probe (P/N HQ40d multimeter). The concentration of organic carbon, available phosphorus and total nitrogen were determined using the Van Reeuwijk (1993), Olsen (1954) and Kjeldahl (Bremner 1960) methods, respectively. The physicochemical parameters (temperature, $\mathrm{pH}, \mathrm{EC}$, organic carbon, total nitrogen, $C / N$ ration and available phosphorous) data were analyzed with Statistical Analysis System (v. 9.2, SAS Institute Inc., Cary, NC USA,) software. Furthermore, the mean significant difference between the compost types was declared using $\operatorname{LSD}(P=0.05)$. The concentration of potassium and heavy metals $(\mathrm{Cd}, \mathrm{Cr}, \mathrm{Cu}, \mathrm{Ni}, \mathrm{Pb}, \mathrm{Zn}, \mathrm{Fe}$ and $\mathrm{Mn})$ of the composted samples was analyzed only for matured and stable compost.

\section{Methods of digestion for heavy metal concentration analysis}

The potassium and heavy metal concentration of the matured and stable compost samples were analyzed at the Environmental Public Health Laboratory of Ethiopian Public Health Institute, Addis Ababa, Ethiopia, using atomic absorption

Table 1 Composition of composting piles and their category

\begin{tabular}{|c|c|c|}
\hline $\begin{array}{l}\text { Compost pile } \\
\text { number }\end{array}$ & Composition & Compost ID \\
\hline $1-3$ & Coffee husk & $\mathrm{C} 1$ \\
\hline $4-6$ & $1 / 2$ coffee husk and $1 / 2$ SSMSW which is composed of fruits, vegetables and Khat (Catha edulis) & $\mathrm{C} 2$ \\
\hline $7-9$ & SSMSW composed of fruits, vegetables and Khat/Catha edulis & $\mathrm{C} 3$ \\
\hline $10-12$ & $1 / 3$ coffee husk, $1 / 3$ SSMSW composed of fruits, vegetables and Khat and $1 / 3$ soft dry wood & $\mathrm{C} 4$ \\
\hline $13-15$ & Coffee pulp & C5 \\
\hline $16-18$ & $\begin{array}{l}1 / 2 \text { coffee pulp and } 1 / 2 \text { leaves of false banana (Ensete ventricosum), which is commonly known by the } \\
\text { name of Ethiopian banana }\end{array}$ & C6 \\
\hline 19-21 & Leaves of false banana & $\mathrm{C} 7$ \\
\hline $22-24$ & $1 / 3$ coffee pulp, $1 / 3$ leaves of false banana and $1 / 3$ soft dry wood & $\mathrm{C} 8$ \\
\hline
\end{tabular}


spectrometry (AAS). The analysis was performed following the method developed by Hseu (2004).

\section{Germination and vegetable productivity test of the matured compost samples}

Before sowing the seed of cabbage on the composted samples, equal proportions of compost samples $(1 \mathrm{~kg}$ each) were filled in plastic bags and watered with tap water to make the compost samples wet for a few days. Afterward, each seed of the cabbage was sown on the stable and final composted samples. To check the maturity of the produced compost samples, the vegetable cabbage (Brassica oleracea) seed was sown on the $1 \mathrm{~kg}$ of composted samples using the local soil as a control. Biochar is used to assess whether the fresh head weight of the cabbage (productivity) is increased or not by using biochar. Thus, $10 \mathrm{~g}$ of the biochar sample that was prepared from the mix of different coffee waste samples (husk, parchment, silver skin, spent coffee and pulp) at equal proportions was used for germination, growth and productivity tests. Thus, the ratio of biochar sample to soil/ composted sample is only $1 \%(\mathrm{wt} / \mathrm{wt})$. Cabbage (Brassica oleracea) was chosen for the study because it is a common vegetable, which is grown and used by the local communities, where the field trail was conducted. The germination study was conducted in the shade to prevent excess water loss and wilting of the seedlings. Afterward, the germinated seedlings were transplanted to the local soil with their plastics cover. Each seedling was monitored carefully, and the final fresh head weight of the cabbage was noted.

\section{Results and discussion}

The surface of the composting mixture is adjusted with the moisture content of $50-60 \%$ by sprinkling water on the feedstock to optimize the composting parameters as suggested by Tiquia et al. (1998), and the results of the weekly average temperature of the composting piles are shown in Fig. 1.

\section{Temperature $\left({ }^{\circ} \mathrm{C}\right)$}

As shown in Fig. 1, C1 and C5 compost types have a higher mesophilic temperature range until the tenth week of composting, and C6 and C7 compost types have a lower mesophilic temperature than the other compost types. The sharp decrement of temperature in $\mathrm{C} 6$ and $\mathrm{C} 7$ compost types during the composting process could be a result of a lower level of microbial activity due to a lower availability of easily degradable organic materials. This might be due to the fact that during composting, microorganisms can degrade the organic matter producing heat, $\mathrm{NH}_{3}, \mathrm{CO}_{2}$, organic acids and water vapor (Bernal et al. 2009). The produced heat is trapped within the pile causing the phenomenon of selfheating, which is a key factor for the increase in the temperature of the heap at the beginning stage of composting (Ryckeboer et al. 2003).

Types of composts showed a highly significant effect on the mean temperature $(P<0.0001)$. Highly significant differences in mean temperature were recorded between the compost types $\mathrm{C} 1$ and $\mathrm{C} 4 ; \mathrm{C} 1$ and $\mathrm{C} 6 ; \mathrm{C} 1$ and $\mathrm{C} 7 ; \mathrm{C} 2$ and $\mathrm{C} 7$; $\mathrm{C} 3$ and $\mathrm{C} 5$; $\mathrm{C} 5$ and $\mathrm{C} 6$; $\mathrm{C} 5$ and $\mathrm{C} 7$; 6 and $\mathrm{C} 8$; $\mathrm{C} 7$ and $\mathrm{C} 8$ with the $P$ value $0.0002,0.0055,0.0001,0.0001$, $0.0055,0.0028,0.0009,0.0001,0.0044$ and 0.0003 , respectively $\left(\mathrm{LSD}_{0.05}=1.0804\right)$. These differences in temperature might be due to the differences in the nutrient content (carbohydrates, fats, amino acids, cellulose, hemicelluloses and lignin) of the source materials, the presence/absence of volatile/nonvolatile compounds, moisture content, the mixing ratio, particle size of the feedstock, aeration, mechanical structure, porosity, the availability and abundance of microorganisms as well as the interaction within the composted materials during composting.

It is a usual trend in composting process that during the beginning stage, the temperature increases sharply and then
Fig. 1 Temperature of composting piles versus the duration of composting. ${ }^{*} \mathrm{C}=$ Compost type

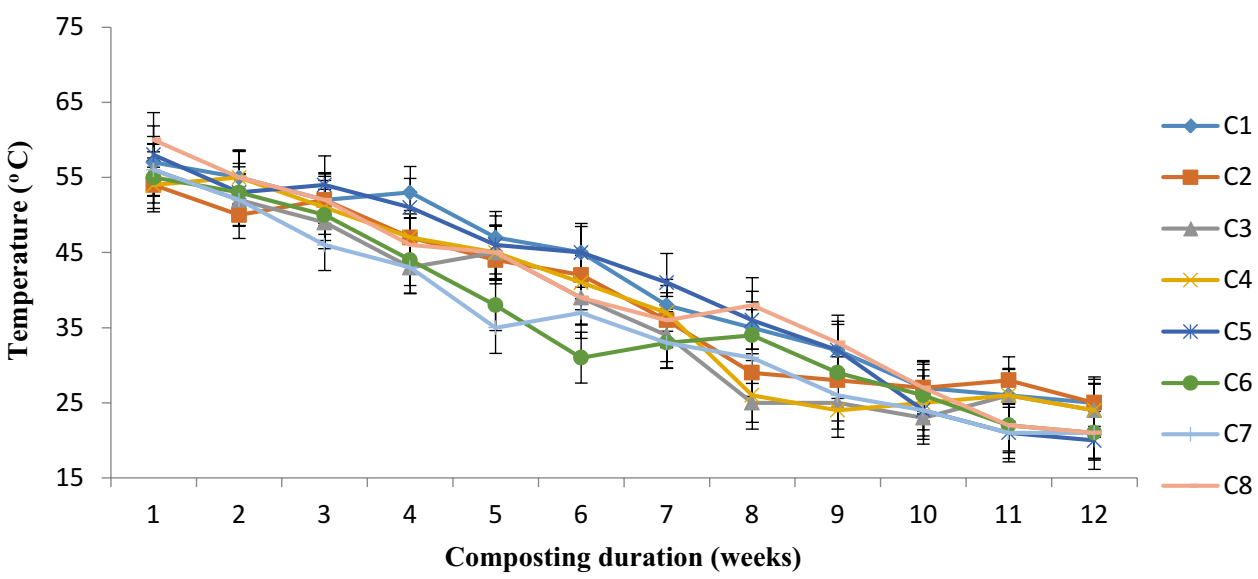


reaches optimum in the active phase, and finally returns back to normal ambient temperature in the final stage (Hassen et al. 2001). The regulation of the temperature is required for controlled composting. In this regard, the study of Miller (1993) indicated that the temperature of $52-60{ }^{\circ} \mathrm{C}$ is the most suitable for decomposition. In general, as composting proceeds, the temperature of all of the compost types declines, which is in agreement with previous studies (Dadi et al. 2012). At the initial phase of the composting process, all the piles were in a thermophilic stage and the temperature exceeded $55{ }^{\circ} \mathrm{C}$. However, the temperature started to decline to $25{ }^{\circ} \mathrm{C}$ and below during the final stage of composting (Getahun et al. 2012b).

\section{pH}

As shown in Fig. 2, the $\mathrm{pH}$ of all of the compost piles varied within weeks in an irregular way. However, starting from the tenth week of composting period, the $\mathrm{pH}$ value was stabilized due to the buffering nature of humic substances (Preethu et al. 2007). For compost types C1, C2 and C7, in general, the $\mathrm{pH}$ was found to decrease starting from the first week of composting, while for the others, the $\mathrm{pH}$ was found to increase. The decrease in $\mathrm{pH}$ of decomposing organic materials might be due to the production of organic acids, phenolic compounds and the further increase in $\mathrm{pH}$ might be due to the formation of ammonia during decomposition (Preethu et al. 2007). The study of Liu and Price (2011) indicated that during the composting process, the decrease in the $\mathrm{pH}$ could be the phenomenon of the carbon dioxide emission in the composting pile, and the accumulation of organic acids. A pH decrease from about 8.3 at the initial stage of composting to 7.7 in the final phase of composting was also reported by Getahun et al. (2012b). The relatively low $\mathrm{pH}$ of $\mathrm{C} 4$ may be due to the presence of acids in these materials, which is in agreement with the study of Preethu et al. (2007).
Types of composts showed a highly significant effect on mean $\mathrm{pH}(P<0.0001)$. Highly significant differences in mean $\mathrm{pH}$ were recorded between the compost types $\mathrm{C} 1$ and C3; $\mathrm{C} 1$ and $\mathrm{C} 7$; $\mathrm{C} 2$ and $\mathrm{C} 3$; $\mathrm{C} 2$ and $\mathrm{C} 7$; $\mathrm{C} 3$ and $\mathrm{C} 4$; $\mathrm{C} 3$ and $\mathrm{C} 6$; $\mathrm{C} 3$ and $\mathrm{C} 8$; $\mathrm{C} 4$ and $\mathrm{C} 5$; 4 and $\mathrm{C} 6$; $\mathrm{C} 4$ and $\mathrm{C} 7$; $\mathrm{C} 4$ and $\mathrm{C} 8$; $\mathrm{C} 6$ and $\mathrm{C} 7$; and $\mathrm{C} 7$ and $\mathrm{C} 8$ with the p-value $0.0003,0.0001,0.0001,0.0001,0.0001,0.0020,0.0010$, $0.0001,0.0048,0.0001,0.0091,0.0007$, and 0.0003 , respectively $\left(\mathrm{LSD}_{0.05}=0.1282\right)$. The difference in $\mathrm{pH}$ among the composted types might be due to the differences in the presence/absence of volatile/nonvolatile substances in the feedstock, chemical composition of the starting materials, the mixing ratio and the interaction within the composted materials during composting.

The increase in $\mathrm{pH}$ during the beginning of composting phase might be due to the release of ammonia from ammonification (Bustamante et al. 2008). The presence of volatile fatty acids may also influence the $\mathrm{pH}$ development in the compost piles (Beck et al. 2001; Yusuf 2008). When the $\mathrm{pH}$ of the soil is above 7.2, the ammonium ion will be converted to ammonium gas which can be lost to the atmosphere (Tack 2013). In general, $\mathrm{pH}$ trend is controlled by the combined effects of ammonification and accumulation of organic acids during the composting process (Liu and Price 2011). Finally, for all compost types, the $\mathrm{pH}$ of matured compost samples was measured to be slightly basic $(8.5 \pm 0.0-9.7 \pm 0.0)$. This implies that the matured compost samples of this study are promising and can be used for the treatment of acidic soils since they do not need the addition of chemicals to adjust the $\mathrm{pH}$ before using it for soils.

\section{Electrical conductivity (EC)}

EC values are indicative of concentration of available ions in the compost. Figure 3 suggests that in general, the EC of all compost types (except $\mathrm{C} 3$ ) declines with time. This decrement could be due to ammonia volatilization and mineral salts precipitation (Kassegn et al. 2015). Additionally, the
Fig. $2 \mathrm{pH}$ of composting piles versus the duration of composting. $* \mathrm{C}=$ Compost type

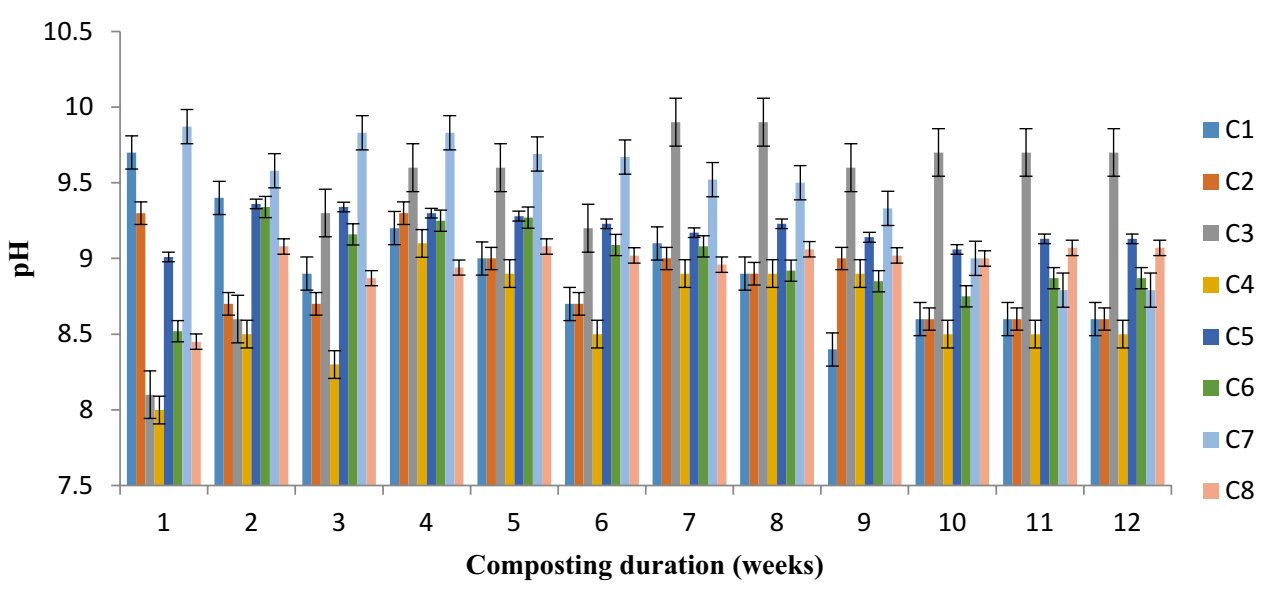


decrement trend in EC during composting could be due to leaching of mineral salts from the composting piles during watering. The same observations were reported by Getahun et al. (2012b). On the contrary, even though there are irregularities, the EC of $\mathrm{C} 3$ compost type was found to increase with time. Similar observations were reported in the literature (Shemekite et al. 2014). The increment in EC could be due to the slight increment of potassium ions $\left(\mathrm{K}^{+}\right)$and other ions during composting. In addition, it might be due to the release of inorganic salts (for example, phosphates and ammonium ions) during the decomposition (Bernal et al. 2009; Liu and Price 2011; Dadi et al. 2012).

Types of composts showed a highly significant effect on mean EC $(P<0.0001)$. Highly significant differences in mean EC were recorded between the compost types $\mathrm{C} 1$ and $\mathrm{C} 3$; $\mathrm{C} 1$ and $\mathrm{C}$; $\mathrm{C} 1$ and $\mathrm{C} 7 ; \mathrm{C} 2$ and $\mathrm{C} 3$; $\mathrm{C} 2$ and $\mathrm{C} 6$; $\mathrm{C} 2$ and $\mathrm{C} 7$; $\mathrm{C} 3$ and $\mathrm{C} 4$; $\mathrm{C} 3$ and $\mathrm{C} 5$; $\mathrm{C} 3$ and $\mathrm{C} 6$; $\mathrm{C} 3$ and $\mathrm{C} 7$; $\mathrm{C} 3$ and $\mathrm{C} 8$; $\mathrm{C} 4$ and $\mathrm{C} 6$; $\mathrm{C} 4$ and $\mathrm{C} 7$; $\mathrm{C} 5$ and $\mathrm{C} 6$; $\mathrm{C} 5$ and $\mathrm{C} 7$; $\mathrm{C} 6$ and $\mathrm{C} 7$; $\mathrm{C} 6$ and $\mathrm{C} 8$; and $\mathrm{C} 7$ and $\mathrm{C} 8$ all with the $P$ value $0.0001\left(\mathrm{LSD}_{0.05}=0.2191\right)$. These differences in $\mathrm{EC}$ among the composted types might be due to the differences in the moisture content, chemical composition of the starting substances, leaching/precipitation of nutrients, the mixing ratio and the interaction within the composted materials during composting.

In general, due to the release of soluble salts, the EC is higher in the final product than in the initial mixture (Huang et al. 2004; Wang et al. 2004); on the contrary, the decrement of EC may be due to ammonia volatilization, and the precipitation as well as the leaching of mineral salts. In general, the EC values of matured compost types were in the common range for most composts and agree with the finding of Yusuf (2008), which indicated the EC values of matured compost samples in the range of $2.19-9.32 \mathrm{mS} / \mathrm{cm}$. Overall, the EC values indicate that application of these matured compost types for agricultural purposes will not damage the crops/ vegetables, as indicated by Mamo (1998), who reported that majority of plants could not withstand soluble salt content beyond $4000 \mathrm{mS} / \mathrm{cm}$. Saline soils contain soluble salts in quantities that can influence plant growth adversely, the lower limit for a saline soil being set conventionally at an electrical conductivity of $4 \mathrm{mmho} / \mathrm{cm}$ in the soil saturation extract (USSLS 1954). In fact, sensitive plants can be affected at half this salinity, and highly tolerant plants at about twice this salinity (Bernstein 1964).

From the results shown in Fig. 3, it can be observed that the $\mathrm{EC}$ value of compost produced from $\mathrm{C} 3$ and $\mathrm{C} 7$, which is composed of SSMSW (fruits, vegetables, Khat/Catha edulis and false-banana leaves), is higher when composted alone than co-composting it with coffee waste. This might be a reason for the observation of highly significant differences for both $\mathrm{C} 3$ and $\mathrm{C} 7$ compost types with all the remaining compost types.

\section{Organic carbon (OC) (\%)}

As shown in Fig. 4, the organic carbon content of all of the compost types declines with time because of the reduction in available carbon sources, and synthesis reactions of the new complex and polymerized organic compounds (humification) during the maturation phase (Bernal et al. 2009). This process leads to stabilized end-products, which act as slow-release fertilizers for agricultural purposes. Kassegn et al. (2015) also indicated that the organic carbon content of compost samples has decreased during composting and reported a \% OC of 55.12 at the initial stage and 15.69 during the final phase. This might be due to the loss of carbon as $\mathrm{CO}_{2}$ as decomposition proceeds, as indicated by Getahun et al. (2012b), who found a loss of carbon from about $44 \%$ at the beginning to $17 \%$ during the maturing phase.

The type of compost showed a highly significant effect on the mean OC $(P<0.0001)$. Highly significant differences in mean OC were recorded between all the compost types except no significant differences were observed between $\mathrm{C} 1$ and $\mathrm{C} 2$; $\mathrm{C} 1$ and $\mathrm{C} 4$; $\mathrm{C} 5$ and $\mathrm{C} 6$; $\mathrm{C} 5$ and $\mathrm{C} 7$; $\mathrm{C} 5$ and $\mathrm{C} 8$; $\mathrm{C} 6$ and $\mathrm{C} 7$; $\mathrm{C} 6$ and $\mathrm{C} 8$; and $\mathrm{C} 7$ and $\mathrm{C} 8$ with the
Fig. 3 Electrical conductivity of composting piles versus the duration of composting. $* \mathrm{C}=$ Compost type

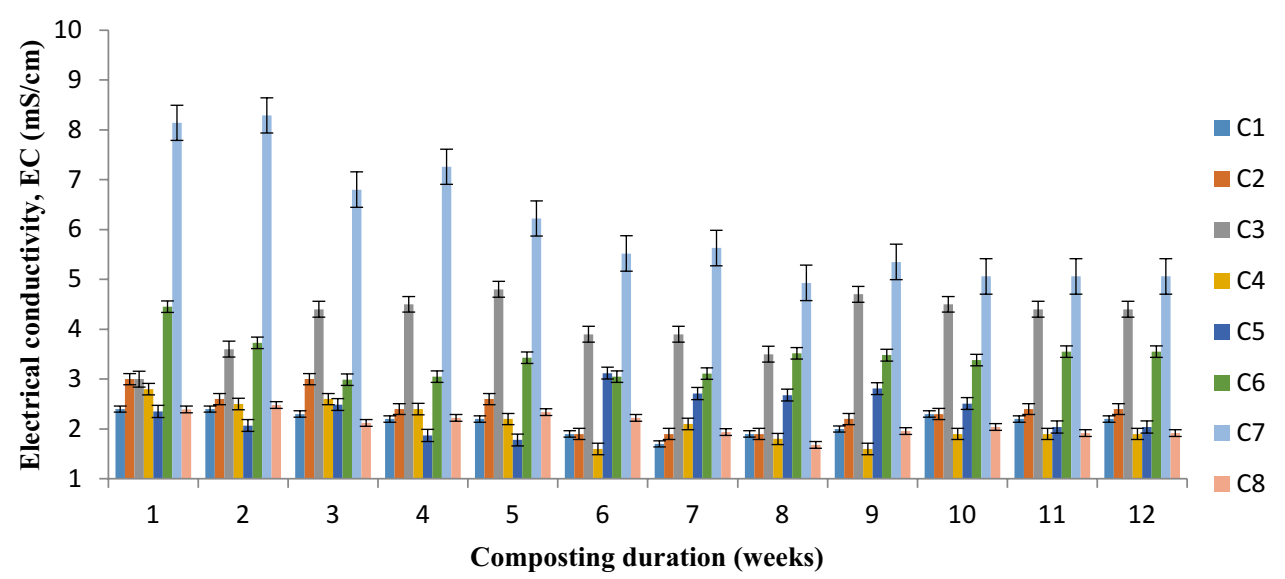


Fig. 4 Organic carbon of composting piles versus the duration of composting. ${ }^{*} \mathrm{C}=$ Compost type

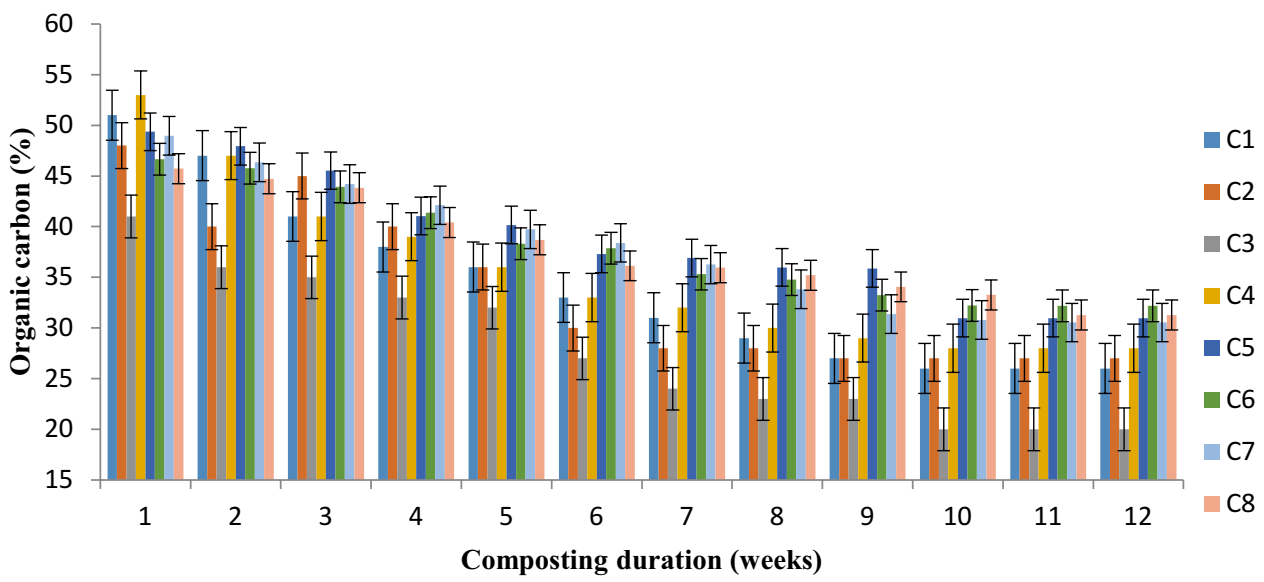

$P$ value $0.3598,0.1385,0.2927,0.2531,0.1541,0.9268$, 0.7050 , and 0.7742 , respectively $\left(\mathrm{LSD}_{0.05}=0.7237\right)$. These differences in OC among the composted types might be due to the differences in the organic/inorganic content as well as the presence/absence of volatile compounds (biochemical composition) of the starting substances, aeration, the mixing ratio and the interaction within the composted materials during composting.

The findings in the present study are consistent for values reported in other conditions (Preethu et al. 2007; Liu and Price 2011; Shemekite et al. 2014). It was observed that comparable amounts of organic carbon were obtained for compost types $\mathrm{C} 1, \mathrm{C} 2$ and $\mathrm{C} 4$ during the maturing stage of the composting process. Similarly, C5, C7 and C8 compost types were observed having a comparable amount of $\mathrm{OC}$ at the maturity phase of composting. However, the organic carbon content of C3 sample was lower than for all the other compost types in almost all stages of the composting process. This might be because of the absence of coffee husk and pulp in the mixture, which has a high lignocellulosic content. Besides, the relatively higher OC content of $\mathrm{C} 6$ compost type may be from the chemical interaction that takes place from the equal mix of coffee pulp and leaves of false banana.

Generally, the organic carbon values were found to decrease during the entire composting period. It has indeed been found that the volume of all composting piles was decreased sharply. The volume reduction might be due to the decomposition of organic matter and hence compaction (Yusuf 2008). These results are in agreement with the study of Anandavalli et al. (1998), which confirmed the reduction in organic carbon with time.

\section{Total nitrogen (TN) (\%)}

The main forms of nitrogen that can be taken up by plants are as either ammonium or nitrate. Figure 5 shows that for $\mathrm{C} 1-\mathrm{C} 4$ composting types, the total nitrogen content declines with time. Turning exposes the raw material to microbial colonization leading to the release of $\mathrm{NH}_{3}$, which is accumulated inside the compost (Ogunwande et al. 2008; Tirado 2008; Kalamdhad and Kazmi 2009; Getahun et al. 2012b). Kassegn et al. (2015) found that the total nitrogen content of compost samples showed a consistently decreasing tendency over the composting time $(1.32 \% \mathrm{TN}$ initially and 1.03
Fig. 5 Total nitrogen of composting piles versus the duration of composting. ${ }^{*} \mathrm{C}=$ Compost type

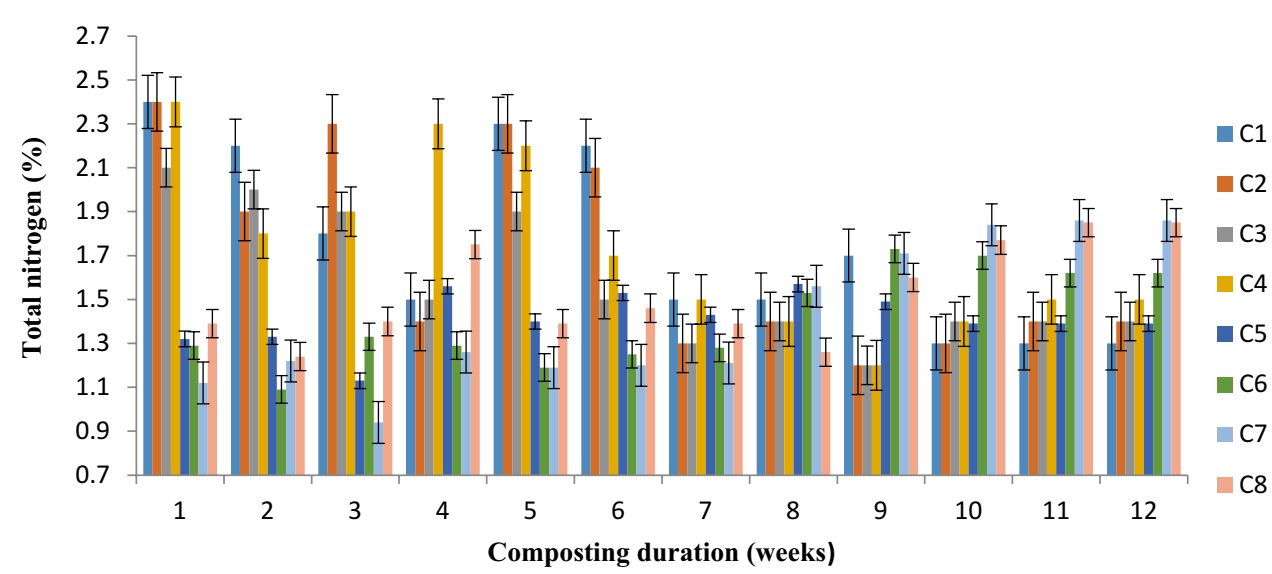


during the final phase). Microorganisms consume carbon and nitrogen for their normal functions; in that, carbon is served as energy source; while nitrogen is used for synthesis of protein by bacteria, which leads to their rapid growth during the beginning phase of composting (Adegunloye et al. 2007; Varma and Kalamdhad 2013).

During the final phase of composting, the TN content of all the composting types was measured to be within the range $1.30 \pm 0.10-1.86 \pm 0.28 \%$. The matured compost samples have a TN over $1 \%$, which indicates that it can have fertilizing capability and might be used in agriculture without additional $N$. These results are supported with the findings of Yusuf (2008), which reported the TN content of matured compost samples in the range of $0.9-1.40 \%$. Similar observations were reported by Dadi et al. (2012). The irregularities in total nitrogen amount of each of the composting types within weeks may be due to variation in decomposition rate of organic matter in the mixture. In support of this, the study of Sánchez-Monedero et al. (2001) indicated that the concentration of the different forms of $\mathrm{N}$ and their evolution during composting depend on the original material.

Contrary to the trend of $\mathrm{C} 1-\mathrm{C} 4$ composting types, the total nitrogen content for all the remaining composting types (C5-C8) was observed to increase with time. These results are in agreement with some other studies (Preethu et al. 2007; Liu and Price 2011; Shemekite et al. 2014), which reported a slight increment in the TN content from the composting of coffee waste as decomposition proceeded. These differences might be due to the difference in the composition and type of composted materials. In support of this, the study of Sánchez-Monedero et al. (2001) indicated that nitrogen loss during composting depends on the feedstock used and on the $\mathrm{pH}$ of the mixture. The study of Yusuf (2008) also indicated that composts can vary depending on the starting materials, extent of decomposition, content (moisture, nutrient, salt), acidity/alkalinity and contaminants (organic and non-organic materials for example heavy metals).

In general, as shown in Fig. 5, the TN content of all of the compost piles varied within weeks in an irregular way. Besides, C6, C7 and C8 compost types were measured to have a higher $\mathrm{TN}$ content than all the remaining composting systems at the maturity stage. This might be from the leaves of false banana, which is a common constituent of the three composting piles.

Types of composts showed a significant effect on mean $\mathrm{TN}(P=0.0243)$. Significant differences in mean $\mathrm{TN}$ were recorded between the compost types of $\mathrm{C} 1$ and $\mathrm{C} 5$; $\mathrm{C} 1$ and $\mathrm{C} 6$; $\mathrm{C} 1$ and $\mathrm{C} 7 ; \mathrm{C} 2$ and $\mathrm{C} 5 ; \mathrm{C} 2$ and $\mathrm{C} 6$; $\mathrm{C} 2$ and $\mathrm{C} 7$; $\mathrm{C} 4$ and $\mathrm{C} 5$; $\mathrm{C} 4$ and $\mathrm{C} 6$; and $\mathrm{C} 4$ and $\mathrm{C} 7$ with the $P$ values $0.0128,0.0126,0.0136,0.0328,0.0323,0.0348,0.0177$, $0.0174,0.0188$, respectively $\left(\mathrm{LSD}_{0.05}=0.1330\right)$. A possible explanation for the differences in TN among the composted types might be due to the differences in the mineralization/ immobilization of nitrogen at different stages of composting, chemical composition (such as fats, amino acids, nitrogen content and forms of nitrogen) of the starting substances, the mixing ratio and the interaction within the composted materials during composting.

\section{Carbon to nitrogen $(C / N)$ ratio}

The $C / N$ ratio is one of the major factors affecting the quality of compost. The results in Figs. 4 and 5 indicated that as the duration of composting increases, from the first week to the 12th week, the organic carbon fraction declines, whereas the total nitrogen concentration varies with time. This implies that the $C / N$ ratio of all composting types varies with time. However, in general, the $C / N$ ratio of all composting types was observed to decline with time, which indicates that a stable product is formed. This is indicated in Fig. 6. Previous studies (Liu and Price 2011; Dadi et al. 2012; Getahun et al. 2012b; Shemekite et al. 2014) also reported a decrement of $C / N$ values with time. Types of composts showed a highly significant effect on mean $C / N(P<0.0001)$.

Highly significant differences in mean $C / N$ were recorded between all the compost types except no significant differences were observed between $\mathrm{C} 1$ and $\mathrm{C} 2 ; \mathrm{C} 1$ and $\mathrm{C} 3 ; \mathrm{C} 1$ and $\mathrm{C} 4 ; \mathrm{C} 2$ and $\mathrm{C} 3 ; \mathrm{C} 2$ and $\mathrm{C} 4 ; \mathrm{C} 3$ and $\mathrm{C} 4 ; \mathrm{C} 5$ and $\mathrm{C} 6$; $\mathrm{C} 5$ and $\mathrm{C} 7 ; \mathrm{C} 5$ and $\mathrm{C} 8$; $\mathrm{C} 6$ and $\mathrm{C} 7 ; \mathrm{C} 6$ and $\mathrm{C} 8 ; \mathrm{C} 7$ and $\mathrm{C} 8$ with the $P$ values $0.9222,0.1824,0.6431,0.1529,0.7145$, $0.0741,0.9582,0.5239,0.1987,0.5585,0.1813$, and 0.0564 , respectively $\left(\mathrm{LSD}_{0.05}=1.8704\right)$. A possible explanation for the differences in $C / N$ among the composted types might be due to the differences in the organic carbon content, the mineralization/immobilization of nitrogen at different stages of composting, chemical composition of the starting feedstock and the role of microorganisms during composting.

During the maturing phase of the composting process, the $C / N$ ratio of $\mathrm{C} 3$ and $\mathrm{C} 7$ compost was found to be the lowest of all compost types. The reason is that $\mathrm{C} 3$ and $\mathrm{C} 7$ compost types had the lowest organic carbon and the highest TN content, respectively, among all compost types (see Figs. 4, 5). In general, during the maturing phase, the compost types $\mathrm{C} 5$ and $\mathrm{C} 1$ were found to have higher $C / N$ values than the others. This might be due to the composition of coffee by-products (coffee husk and pulp) used for composting. In this regard, the findings of Shemekite et al. (2014) clearly confirmed that higher $C / N$ ratios were obtained when coffee husk is composted alone than by co-composting it with either animal manure or fruit/vegetable waste.

A higher $C / N$ ratio at the final phase of the composting process for the coffee pulp and coffee husk compost (C5 and $\mathrm{C} 1$, respectively) was obtained, which is an indicative of a slow kinetic process in this compost. The study of Shemekite et al. (2014) reported that the addition of animal manure and fruit/vegetable waste to coffee husk 
Fig. $6 C / N$ ratio of composting piles versus the duration of composting. ${ }^{*} \mathrm{C}=$ Compost type

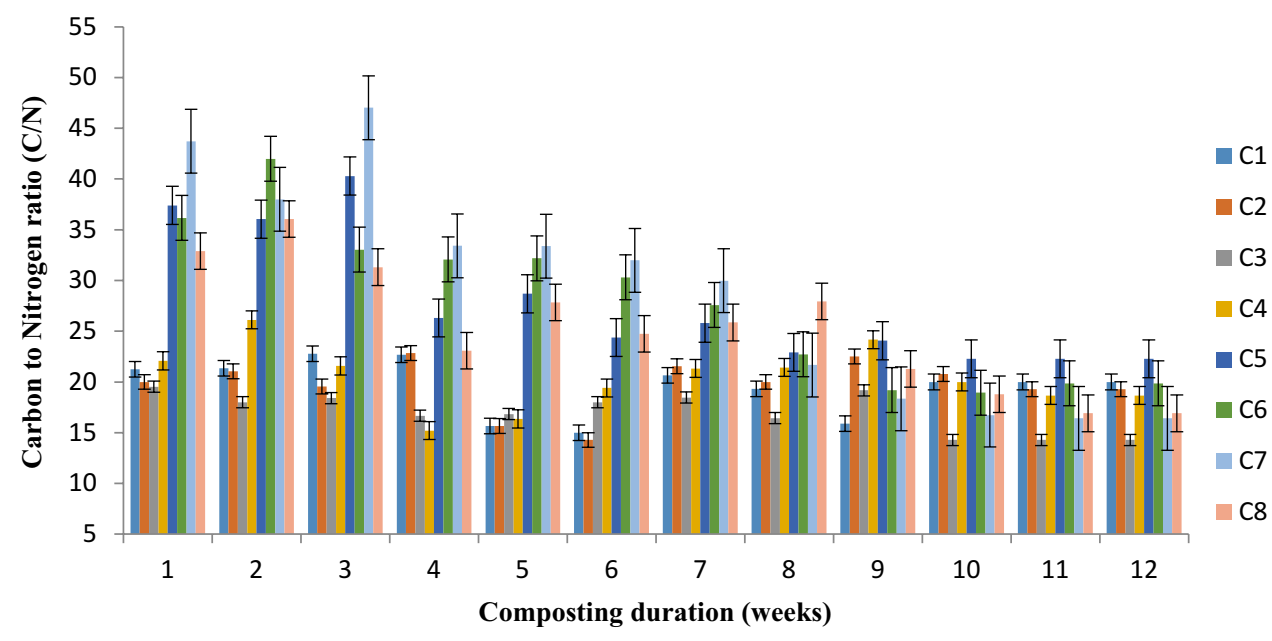

highly contributed to the decomposition of the lignocellulosic compounds of the husk, resulting in higher $N$ losses in these mixed composts. Besides, the study of SánchezMonedero et al. (2001) also confirmed that the addition of by-products with a high lignocellulosic content in the mixtures led to lower $N$ losses during the composting process than the mixture of MSW, which can lose more of its $N$ content.

Although there is no generally agreed method of evaluating compost maturity and stability, checking $C / N$ ratio is repeatedly used as one method for the determination (CCQC 2001). C/N ratio of the final stable compost samples agrees with the suggestions of Liu and Price (2011), which indicated that the produced compost is considered stable as well as mature if it has a $C / N$ ratio of $<25: 1$. Furthermore, the results are within the range recommended by the Ethiopian Environmental Protection Authority (EEPA) good quality compost guidelines, which recommend a $C / N$ ratio of 29:1 or less (EFEPA 2004). Thus, the $C / N$ for the final compost sample obtained in this study, which is in the range of $14.29 \pm 1.68-22.28 \pm 2.56$, lies reasonably in the range which can be used for agricultural purposes. Thus, all the produced compost samples $(\mathrm{C} 1-\mathrm{C} 8)$ can be used for agricultural purposes.

\section{Available phosphorous}

As shown in Fig. 7, the available phosphorous content of all of the compost piles varied within weeks in an irregular way. The increment of available phosphorous within the composting weeks may be from the release of inorganic phosphate from organic phosphates (mineralization), which is caused by microorganisms breaking down organic compounds. On the other side, the decrement of available phosphorous could be due to its leaching or reacting with metal cations in the compost and then producing insoluble phosphates which could be precipitated out (Varma and Kalamdhad 2013). The study of Kassegn et al. (2015) on MSW compost samples reported a decrement of available phosphorus with composting time.

Types of composts showed a highly significant effect on mean AP $(P<0.0001)$. Highly significant difference in mean AP was recorded between C5 compost type with all the rest $\left(\mathrm{LSD}_{0.05}=0.9928\right)$. A possible explanation for the
Fig. 7 Available phosphorous of composting piles versus the duration of composting. * $\mathrm{C}=$ Compost type

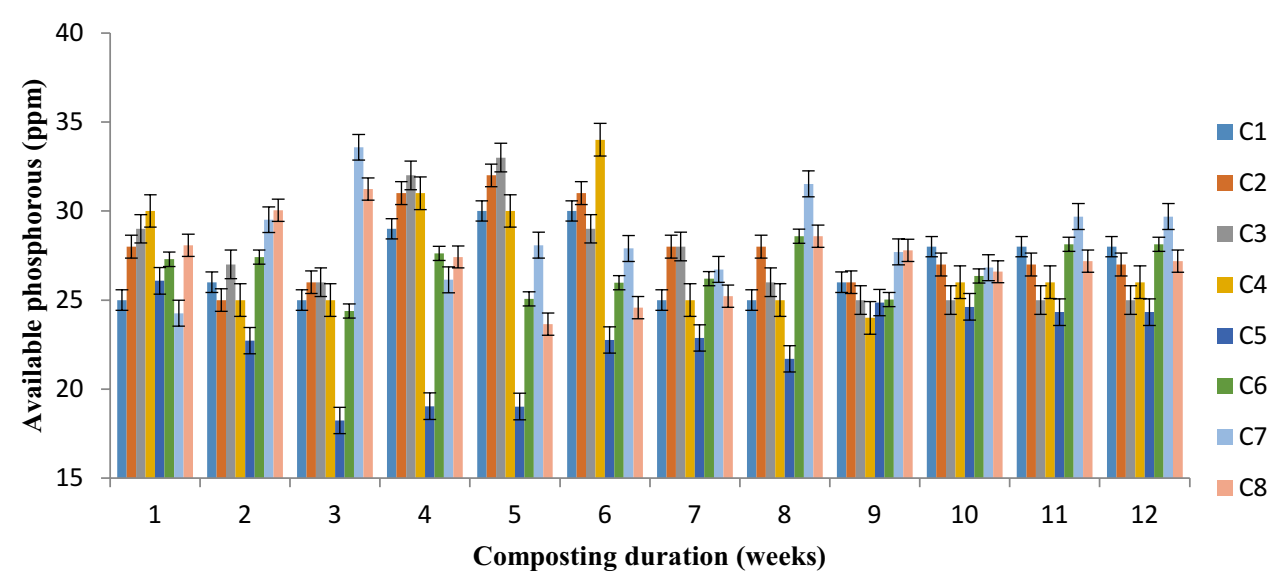


differences in available phosphorus among the composted types might be due to the nutrient content of the starting substances (such as simple carbohydrates, fats, amino acids, cellulose, hemicelluloses and lignin), the mixing ratio, the available microorganisms, stability, maturity and the interaction within the composted materials during composting.

In general, the available phosphorous content for the final compost sample obtained in this study is in the range of $24.32 \pm 1.06-29.69 \pm 1.06 \mathrm{ppm}$. In this regard, Getahun et al. (2012b) reported the total phosphorous content of matured compost samples ranging from 1.61 to $2.24 \mathrm{~g} / \mathrm{kg}$. Yusuf (2008) reported the available phosphorus content of matured compost ranging from 532.00 to $803.00 \mathrm{ppm}$ from Khat and related materials composting. These differences in available phosphorous content might be due to the differences in raw materials used for composting, composting system and composting time. $\mathrm{C} 5$ and $\mathrm{C} 7$ composts were measured to have the lowest and highest content of available phosphorous, respectively, among all compost types.

\section{Available potassium}

The concentration of available potassium in matured and stable compost samples C1, C2, C3, C4, C5, C6, C7 and C8 was measured to be $466.50 \pm 88.77,458.17 \pm 103.24$, $459.00 \pm 68.05,360.67 \pm 36.43,485 \pm 44,426 \pm 36,471 \pm 43$ and $403 \pm 33 \mathrm{mg} / \mathrm{kg}$, respectively. The highest concentration of potassium was detected in C5 and C7 composts, and the lowest concentration of potassium was detected in $\mathrm{C} 4$ and $\mathrm{C} 8$ compost samples among all compost samples. The relatively higher $\mathrm{K}$ content measured in the composts may be due to the higher concentration of $K$ in the raw materials (i.e., in coffee pulp and the leaves of false banana, respectively). This is supported by the study of Preethu et al. (2007), which reported the compost sample of coffee husk and pulp containing $2.94 \% \mathrm{~K}$. Yusuf (2008) reported the available potassium content of matured compost sample of Khat and related materials to be in the range of 6775.72-12,445.24 ppm. Getahun et al. (2012b) reported a potassium content of matured compost samples ranging from 0.69 to $1.15 \mathrm{~g} / \mathrm{kg}$.

\section{Heavy metals concentration of matured compost samples}

The heavy metal $(\mathrm{Pb}, \mathrm{Cr}, \mathrm{Cd}, \mathrm{Mn}, \mathrm{Zn}, \mathrm{Fe}, \mathrm{Ni}$ and $\mathrm{Cu})$ content of the matured compost samples was analyzed, and the results are shown in Table 2.

As shown in Table 2, the $\mathrm{Pb}$ and $\mathrm{Cr}$ concentrations were below the detection limit of the instrument and were undetected in all compost samples. Ni was detected in all compost samples with the concentration of less than $1 \mathrm{ppm}$. However, it was not detected in $\mathrm{C} 3$ and $\mathrm{C} 4$ composts. This confirmed that coffee husk, pulp and leaves of false banana contained $\mathrm{Ni}$. $\mathrm{Cu}$ was detected uniformly in all the matured compost samples with a concentration below $0.30 \mathrm{mg} / \mathrm{kg}$. Higher concentrations of $\mathrm{Mn}$ in $\mathrm{C} 3$ and $\mathrm{C} 7$, and $\mathrm{Zn}$ in $\mathrm{C} 3$ compost samples were detected than in other compost types. This might be related to the MSW source; for example, it can be from the raw material itself, electronic equipment, packaging materials, dry batteries, etc. $\mathrm{C} 3$ and $\mathrm{C} 4$ compost samples were found to have a higher amount of $\mathrm{Cd}$ than the other compost types. The main source of $\mathrm{Cd}$ in these compost samples may be from ointments, paints, inks, dry batteries, toys, electronic equipment, etc. in contact with MSW during collection. On the other hand, the highest concentration of iron was detected in C7 compost. Getahun et al. (2012b) reported iron content of matured compost samples ranging from 1.75 to $2.62 \mathrm{~g} / \mathrm{kg}$. A higher iron content of the sample of false banana was also confirmed by Abebe et al. (2007).

In general, the concentrations of all the analyzed metals in the matured compost samples are within the range of compost quality guidelines and standards used by Belgium (for agriculture), the European Union, the USA (for biosolids) and the Canadian Council of Ministers of the Environment (CCME 2005) guidelines for compost quality for unrestricted use.

\section{Germination test and yield of fresh head weight of cabbage}

The results of the growth of cabbage seeds on the matured compost samples, its nature of germination, as well as the yield of the fresh head weight of the grown cabbage are indicated in Table 3. For the germination study, the numbers of seeds that are germinating were counted and all seeds were found to germinate and grew on composted samples. This, in turn, implies that all the produced compost samples were rated very mature since all the sown cabbage seeds (Brassica oleracea) were germinating and grew.

According to Zucconi et al. (1981), a germination index below $50 \%$ characterizes an immature compost. According to TMECC (2002), a compost with a $C / N>25$ is immature. Immature and poorly stabilized composts may pose a number of problems during storage, marketing and use (Bernal et al. 2009). Therefore, as indicated in Table 3 , all the produced compost samples were rated very mature since all the sown cabbage seeds (Brassica oleracea) were germinating and grew. This implies that the produced compost samples are free of plant phytotoxic materials (Dadi et al. 2012). Furthermore, the seeds of cabbage were observed to grow very slowly when the local soil alone as well as $3 / 4$ of local soil and $1 / 4$ th of compost samples of all types $(\mathrm{C} 1-\mathrm{C} 8)$ were used. In addition, the fresh head weight of the cabbage yield obtained was also very low. This might be due to lack of 


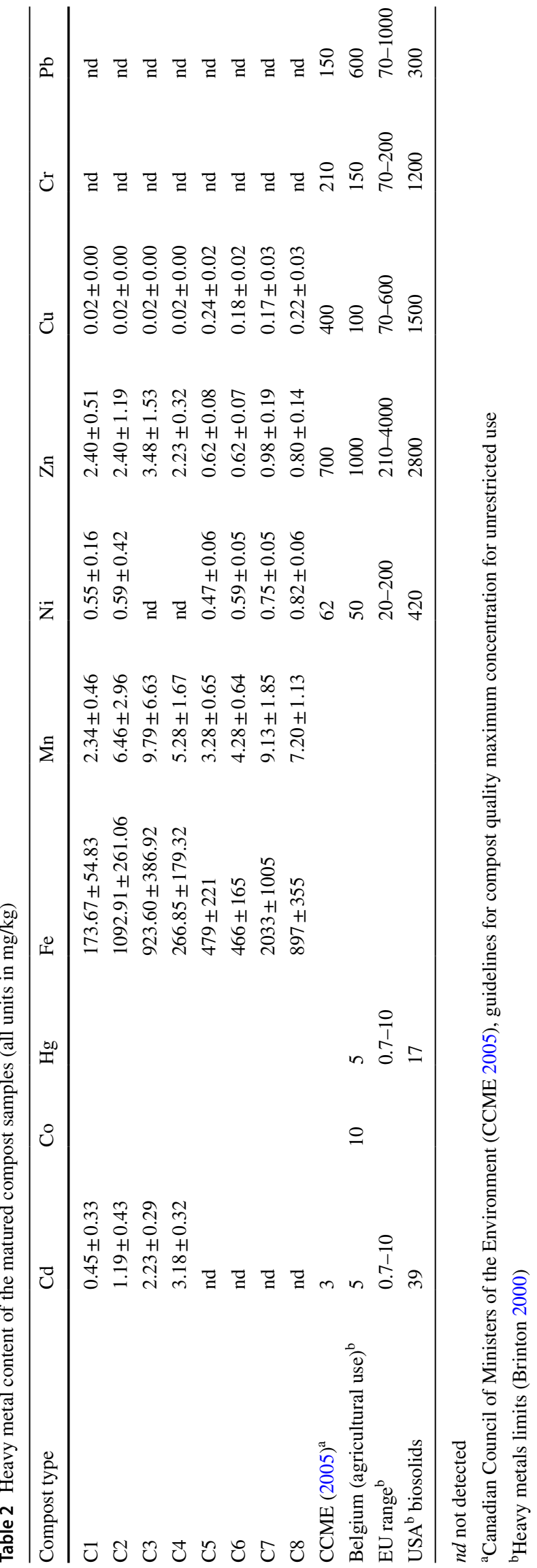

nutrients in the local soil or lack of suitable environmental factors such as acidity/basicity of the soil.

On the contrary, the seeds were observed to grow very fast in different mixes of composts, mixed in different proportions with local soil (either $1 / 2$ or $1 / 4$ ), and with composts mixed with $1 \%(\mathrm{wt} / \mathrm{wt}$ ) biochar. In addition, the obtained fresh head weight of the cabbage was also higher. The variation in yield of fresh head weight of the cabbage among these treatments might be due to differences in their content of available nutrients (Getahun et al. 2012b). In this regard, the study of Dume et al. (2015) confirmed that the application of coffee husk biochar to acidic soils showed a better improvement in soil chemical properties ( $\mathrm{pH}$, electrical conductivity, cation exchange capacity, organic carbon/matter, total nitrogen, exchangeable cations and available phosphorous). The study of Maggen et al. (2017) also proved that the survival and production of plant growth, crops (dwarf beans), and worm (Eisenia fetida) are found to be affected positively with $2 \mathrm{wt} \%$ blending of biochar derived from the dry and solid fraction of pig manure with a poor soil. The same study also confirmed that by using the char, the available heavy metals are immobilized in the biochar and not leachable.

The results clearly indicate that using mature compost produced from $\mathrm{C} 8$ compost type (co-composting of $1 / 3 \mathrm{rd}$ of leaves of false banana, 1/3rd of coffee pulp, and 1/3rd soft dry woods) mixed with different proportions of local soil could result in a higher fresh head weight of the cabbage, which ranges from $422 \pm 8$ to $572 \pm 10 \mathrm{~g} / \mathrm{kg}$ of compost. This indicates that by mixing different types of composts in different ratios, by adding a lower amount of local soil and with the addition of biochars, an optimum yield of the fresh head weight of the cabbage is obtained. In addition, when $\mathrm{C} 8$ compost type is mixed with local soil in 3:1 ratio, it could yield an optimum fresh head weight of the cabbage ( $572 \pm 10 \mathrm{~g} / \mathrm{kg}$ of compost). This might be due to the relatively higher concentration of total nitrogen in the $\mathrm{C} 8$ compost sample.

\section{Conclusions}

This study confirms that the two major coffee by-products (husk and pulp) can be successfully composted alone or co-composted with other degradable fractions of municipal solid waste in different ratios producing very mature compost, which is stabilized and sanitized ensuring its optimum benefit for agriculture. From the results, the highest $\mathrm{pH}$ (in C3), EC (in C7), TN (in C7 and C8), available phosphorus (in C7), iron (in C7), potassium (in $\mathrm{C} 5$ and $\mathrm{C} 7$ ), $C / N$ (in $\mathrm{C} 3$ and $\mathrm{C} 1$ ), and lowest $\mathrm{OC}$ and $\mathrm{OM}$ (in $\mathrm{C} 3$ ) and iron (in $\mathrm{C} 1$ ) were detected in these compost samples. $\mathrm{C} / \mathrm{N}$ ratio of final compost samples is within the range of 
Table 3 Germination, growth and yield productivity test on composted samples

\begin{tabular}{|c|c|c|c|c|c|}
\hline S. no. & $\begin{array}{l}\text { Type of applied } \\
\text { compost }\end{array}$ & Amount of local soil & $\begin{array}{l}\text { Amount of biochar } \\
\text { used }(\mathrm{g})\end{array}$ & Nature of germination & $\begin{array}{l}\text { Head weight of the cabbage } \\
\text { (g) per kg of compost (soil) }\end{array}$ \\
\hline 1. & - & $100 \%$ & - & Very slow & $94 \pm 8$ \\
\hline 2. & $\mathrm{C} 1$ & - & - & Moderate & $134 \pm 4$ \\
\hline 3. & 3/4th C1 & 1/4th soil & - & Moderate & $146 \pm 5$ \\
\hline 4. & $1 / 2 \mathrm{C} 1$ & $1 / 2$ soil & - & moderate & $160 \pm 6$ \\
\hline 5. & 1/4th C1 & 3/4th soil & - & Slow & $116 \pm 6$ \\
\hline 6. & $1 / 2 \mathrm{C} 1$ & $1 / 2$ soil & 10 & Fast & $172 \pm 6$ \\
\hline 7. & $\mathrm{C} 1$ & - & 10 & Moderate & $146 \pm 4$ \\
\hline 8. & - & Soil & 10 & Slow & $108 \pm 4$ \\
\hline 9. & $\mathrm{C} 2$ & - & - & Moderate & $221 \pm 7$ \\
\hline 10. & 3/4th C2 & 1/4th soil & - & Moderate & $202 \pm 8$ \\
\hline 11. & $1 / 2 \mathrm{C} 2$ & $1 / 2$ soil & - & Moderate & $191 \pm 6$ \\
\hline 12. & 1/4th C2 & 3/4th soil & - & Slow & $178 \pm 10$ \\
\hline 13. & $1 / 2 \mathrm{C} 2$ & $1 / 2$ soil & 10 & Fast & $204 \pm 10$ \\
\hline 14. & $\mathrm{C} 2$ & - & 10 & Moderate & $217 \pm 6$ \\
\hline 15. & $\mathrm{C} 3$ & - & - & Moderate & $171 \pm 9$ \\
\hline 16. & 3/4th C3 & 1/4th soil & - & Moderate & $171 \pm 8$ \\
\hline 17. & 1/2 C3 & $1 / 2$ soil & - & Moderate & $155 \pm 8$ \\
\hline 18. & 1/4th C3 & 3/4th soil & - & Slow & $155 \pm 5$ \\
\hline 19. & $1 / 2 \mathrm{C} 3$ & $1 / 2$ soil & 10 & Fast & $163 \pm 5$ \\
\hline 20. & $\mathrm{C} 3$ & - & 10 & Moderate & $178 \pm 4$ \\
\hline 21. & $\mathrm{C} 4$ & - & - & Fast & $276 \pm 6$ \\
\hline 22. & 3/4th C4 & 1/4th soil & - & Fast & $260 \pm 7$ \\
\hline 23. & $1 / 2 \mathrm{C} 4$ & $1 / 2$ soil & - & Fast & $218 \pm 5$ \\
\hline 24. & 1/4th C4 & 3/4th soil & - & Moderate & $173 \pm 6$ \\
\hline 25. & $1 / 2 \mathrm{C} 4$ & $1 / 2$ soil & 10 & Fast & $226 \pm 5$ \\
\hline 26. & $\mathrm{C} 4$ & - & 10 & Fast & $279 \pm 7$ \\
\hline 27. & C5 & - & - & Slow & $107 \pm 3$ \\
\hline 28. & 3/4th C5 & 1/4th soil & - & Moderate & $125 \pm 13$ \\
\hline 29. & $1 / 2$ C5 & $1 / 2$ soil & - & Moderate & $133 \pm 10$ \\
\hline 30. & 1/4th C5 & 3/4th soil & - & Moderate & $118 \pm 8$ \\
\hline 31. & $1 / 2 \mathrm{C} 5$ & $1 / 2$ soil & 10 & Fast & $140 \pm 5$ \\
\hline 32. & $\mathrm{C} 5$ & - & 10 & Moderate & $117 \pm 8$ \\
\hline 33. & C6 & - & - & Moderate & $302 \pm 10$ \\
\hline 34. & 3/4th C6 & 1/4th soil & - & Moderate & $287 \pm 10$ \\
\hline 35. & $1 / 2$ C6 & $1 / 2$ soil & - & Moderate & $278 \pm 8$ \\
\hline 36. & 1/4th C6 & 3/4th soil & - & Slow & $225 \pm 5$ \\
\hline 37. & $1 / 2$ C6 & $1 / 2$ soil & 10 & Fast & $288 \pm 10$ \\
\hline 38. & C6 & - & 10 & Moderate & $212 \pm 8$ \\
\hline 39. & $\mathrm{C} 7$ & - & - & Moderate & $243 \pm 10$ \\
\hline 40. & 3/4th C7 & 1/4th soil & - & Moderate & $252 \pm 10$ \\
\hline 41. & $1 / 2 \mathrm{C} 7$ & $1 / 2$ soil & - & Moderate & $192 \pm 10$ \\
\hline 42. & 1/4th C7 & 3/4th soil & - & Slow & $175 \pm 10$ \\
\hline 43. & $1 / 2 \mathrm{C} 7$ & $1 / 2$ soil & 10 & Fast & $202 \pm 10$ \\
\hline 44. & $\mathrm{C} 7$ & - & 10 & Moderate & $253 \pm 10$ \\
\hline 45. & $\mathrm{C} 8$ & - & - & Fast & $533 \pm 13$ \\
\hline 46. & 3/4th C8 & 1/4th soil & - & Fast & $572 \pm 10$ \\
\hline 47. & $1 / 2 \mathrm{C} 8$ & $1 / 2$ soil & - & Fast & $482 \pm 15$ \\
\hline 48. & 1/4th C8 & 3/4th soil & - & Moderate & $422 \pm 8$ \\
\hline 49. & $1 / 2 \mathrm{C} 8$ & $1 / 2$ soil & 10 & Fast & $493 \pm 10$ \\
\hline
\end{tabular}


Table 3 (continued)

\begin{tabular}{|c|c|c|c|c|c|}
\hline S. no. & $\begin{array}{l}\text { Type of applied } \\
\text { compost }\end{array}$ & Amount of local soil & $\begin{array}{l}\text { Amount of biochar } \\
\text { used }(\mathrm{g})\end{array}$ & Nature of germination & $\begin{array}{l}\text { Head weight of the cabbage } \\
\text { (g) per kg of compost (soil) }\end{array}$ \\
\hline 50. & C8 & - & 10 & Fast & $545 \pm 10$ \\
\hline
\end{tabular}

$<25: 1$. The major contribution of matured compost samples of coffee husk and pulp is that they contributed the elements iron and potassium. Besides, they also contain other micronutrients which are essential to plant growth (which are required in much smaller amounts than the macronutrients), such as copper, manganese, zinc, nickel and zinc. Furthermore, reasonable concentrations of heavy metals without restrictions which can be used for agricultural purposes were observed in all compost types and all are in the range of compost guidelines and standards set by Ethiopia, Belgium (for agriculture), the European Union and the USA (for biosolids). In general, the results clearly indicate that using mature compost produced from C8 compost type ((co-composting of 1/3rd of leaves of false banana (Ensete ventricosum), 1/3rd of coffee pulp and $1 / 3$ rd soft dry woods) mixed with different proportions of local soil could result in a higher fresh head weight of the cabbage. In addition, when C8 compost type is mixed with local soil in 3:1 ratio, it could yield an optimum fresh head weight of the cabbage $(572 \pm 10 \mathrm{~g} / \mathrm{kg}$ of compost). This could be due to the relatively higher concentration of total nitrogen in the $\mathrm{C} 8$ compost sample. Furthermore, before producing and applying compost samples on soil, first of all, the chemistry of the local soil should be studied in detail. For example, if the $\mathrm{pH}$ of the soil is acidic, the produced compost should be slightly basic; otherwise, it can affect the local soil and hence it is the loss of energy, time and resources. Besides, if the soil lacks nutrients, for example, potassium, the produced compost should be rich enough in its content of potassium.

Acknowledgements The authors would like to thank coffee industry owners, managers and daily laborers working in wet and dry coffee processing industries existing in Jimma zone for thier permission and cooperation during the entire sample collection. Besides, the authors also would like to thank the VLIR-UOS project of Belgium and Jimma University, Ethiopia for financial support.

Funding This work has been supported by the Institutional University Cooperation Program (IUC) VLIR-UOS project of Belgium and Jimma University, Ethiopia.

\section{Compliance with ethical standards}

Conflict of interest The authors would like to declare that there is no conflict of interest with this research.
Open Access This article is distributed under the terms of the Creative Commons Attribution 4.0 International License (http://creativeco mmons.org/licenses/by/4.0/), which permits unrestricted use, distribution, and reproduction in any medium, provided you give appropriate credit to the original author(s) and the source, provide a link to the Creative Commons license, and indicate if changes were made.

\section{References}

Abebe Y, Bogale A, Hambidge KM, Stoecker BJ, Bailey K, Gibson RS (2007) Phytate, zinc, iron and calcium content of selected raw and prepared foods consumed in rural Sidama, Southern Ethiopia, and implications for bioavailability. J Food Compos Anal 20:161-168. https://doi.org/10.1016/j.jfca.2006.09.003

Adegunloye D, Adetuyi F, Akinyosoye F, Doyeni M (2007) Microbial analysis of compost using cowdung as booster. Pak J Nutr 6:506-510

Anandavalli D, Ramaswami P, Hameed S (1998) Recycling of banana pseudostem as compost. J Ecotoxicol Environ Monit 8:191-194

Beck FB, Smars S, Jonsson H (2001) Gaseous emissions of carbon dioxide, ammonia and nitrous oxide from organic household waste in a composting reactor under different temperature regimes. J Agric Eng Res 78:423-430. https://doi.org/10.1006/ jaer.2000.0662

Bernal MP, Alburquerque J, Moral R (2009) Composting of animal manures and chemical criteria for compost maturity assessment. A review. Bioresour Technol 100:5444-5453. https://doi. org/10.1016/j.biortech.2008.11.027

Bernstein L (1964) Salt tolerance of plants. US department of agriculture (USDA). Agric Inf Bull 283:23

Bremner J (1960) Determination of nitrogen in soil by the Kjeldahl method. J Agric Sci 55:11-33. https://doi.org/10.1017/S0021 859600021572

Brinton WF (2000) Compost quality standards and guidelines: an international view. Final Report by Woods End Research Laboratories for the New York State Association of Recyclers

Bustamante M, Paredes C, Marhuenda-Egea F, Pérez-Espinosa A, Bernal M, Moral R (2008) Co-composting of distillery wastes with animal manures: carbon and nitrogen transformations in the evaluation of compost stability. Chemosphere 72:551-557. https ://doi.org/10.1016/j.chemosphere.2008.03.030

CCME (2005) Canadian council of ministers of the environment (CCME), guidelines for compost quality, Canada, pp 1-21

CCQC (2001) California compost quality council (CCQC). Nevada City, California

Dadi D, Sulaiman H, Leta S (2012) Evaluation of composting and the quality of compost from the source separated municipal solid waste. J Appl Sci Environ Manag 16:5-10

De Rezende FA, Eric GJDC, Ferreira B (2012) Composting of coffee husk and cattle manure. Revista de Ciências Agro-Ambientais, Alta Floresta-MT 10(1):109-119 
Degefe G, Mengistou S, Mohammed S (2016) Physico chemical evaluation of coffee husk, wastes of enset (Enset ventricosum), vegetable and khat (Catha edulis) through vermicomposting employing an epigeic earthworm Dendrobaena veneta (Rosa, 1886). Afr J Biotechnol 15:884-890. https://doi.org/10.5897/AJB2015.14676

Dume B, Berecha G, Tulu S (2015) Characterization of biochar produced at different temperatures and its effect on acidic nitosol of Jimma, Southwest Ethiopia. Int J Soil Sci 10:63-73. https://doi. org/10.3923/ijss.2015.63.73

Echeverria M, Nuti M (2017) Valorisation of the residues of coffee agro-industry: perspectives and limitations. Open Wast Manag J 10:13-22. https://doi.org/10.2174/1876400201710010013

EFEPA (2004) Ethiopian federal environmental protection authority (EFEPA): guidelines on composting, Addis Ababa, Ethiopia, pp $1-5$

Franca AS, Oliveira LS (2009) Coffee processing solid wastes: current uses and future perspectives. In: Ashworth GS, Azevedo P (eds) Agricultural wastes. Nova Science Publishers Inc, New York, pp 155-189

Gajalakshmi S, Abbasi S (2008) Solid waste management by composting: state of the art. Crit Rev Environ Sci Technol 38:311400. https://doi.org/10.1080/10643380701413633

Gazi A, Kyriacou A, Kotsou M, Lasaridi K (2007) Microbial community dynamics and stability assessment during green waste composting. Glob NEST J 9:35-41

Geisshüsler S, Brenneisen R (1987) The content of psychoactive phenylpropyl and phenylpentenyl khatamines in Catha edulis Forsk of different origin. J Ethnopharmacol 19:269-277. https ://doi.org/10.1016/0378-8741(87)90004-3

Getahun T, Mengistie E, Haddis A, Wasie F, Alemayehu E, Dadi D, Van Gerven T, Van der Bruggen B (2012a) Municipal solid waste generation in growing urban areas in Africa: current practices and relation to socioeconomic factors in Jimma, Ethiopia. Environ Monit Assess 184:6337-6345. https://doi.org/10.1007/ s10661-011-2423-x

Getahun T, Nigusie A, Entele T, Van Gerven T, Van der Bruggen B (2012b) Effect of turning frequencies on composting biodegradable municipal solid waste quality. Resour Conserv Recycl 65:79-84. https://doi.org/10.1016/j.resconrec.2012.05.007

Hassen A, Belguith K, Jedidi N, Cherif A, Cherif M, Boudabous A (2001) Microbial characterization during composting of municipal solid waste. Bioresour Technol 80:217-225. https:// doi.org/10.1016/S0960-8524(01)00065-7

Hseu ZY (2004) Evaluating heavy metal contents in nine composts using four digestion methods. Bioresour Technol 95:53-59. https://doi.org/10.1016/j.biortech.2004.02.008

Huang G, Wong J, Wu Q, Nagar B (2004) Effect of C/N on composting of pig manure with sawdust. Waste Manag 24:805-813. https://doi.org/10.1016/j.wasman.2004.03.011

Hue N, Bittenbender H, Ortiz-Escobar M (2006) Managing coffee processing water in Hawaii. J Hawaii Pac Agric 13:15-21

Kalamdhad AS, Kazmi A (2009) Effects of turning frequency on compost stability and some chemical characteristics in a rotary drum composter. Chemosphere 74:1327-1334. https://doi. org/10.1016/j.chemosphere.2008.11.058

Kassa H, Suliman H, Workayew T (2011) Evaluation of composting process and quality of compost from coffee by-products (Coffee Husk \& Pulp). Ethiop J Environ Stud Manag 4:8-13. https://doi. org/10.4314/ejesm.v4i4.2

Kassegn G, Hiluf K, Gebregziabher G, Degefe G, Kumera B (2015) Physicochemical characterization and microbial identification of compost produced from municipal solid waste in Shewa Robit town, Ethiopia. Res J Agric Environ Sci 2:25-30

Lemma E, Tekilu H (2014) Characterization and disposal of municipal solid waste, case study, Hosanna Town. Am J Environ Eng 4(6):162-168. https://doi.org/10.5923/j.ajee.20140406.04
Liu K, Price G (2011) Evaluation of three composting systems for the management of spent coffee grounds. Bioresour Technol 102:7966-7974. https://doi.org/10.1016/j.biortech.2011.05.073

Maggen J, Carleer R, Yperman J, De Vocht A, Schreurs S, Reggers G, Thijsen E (2017) Biochar derived from the dry, solid fraction of pig manure as potential fertilizer for poor and contaminated soils. Sustain Agric Res 6(2):167-184. https://doi.org/10.5539/ sar.v6n2p167

Mamo M (1998) Utilization of municipal solid waste compost for crop production. University of Minnesota Extension Service, St. Paul

Miller F (1993) Composting as a process based on the control of ecologically selective factors. Soil Microb Ecol 18:515-544

Murthy PS, Naidu MM (2012) Sustainable management of coffee industry by-products and value addition-a review. Resour Conserv Recycl 66:45-58. https://doi.org/10.1016/j.resco nrec.2012.06.005

Ogunwande G, Osunade J, Adekalu K, Ogunjimi L (2008) Nitrogen loss in chicken litter compost as affected by carbon to nitrogen ratio and turning frequency. Bioresour Technol 99:7495-7503. https://doi.org/10.1016/j.biortech.2008.02.020

Olsen SR (1954) Estimation of available phosphorus in soils by extraction with sodium bicarbonate. United States Department of Agriculture (USDA), Washington

Pandey A, Soccol CR, Nigam P, Soccol VT (2000) Biotechnological potential of agro-industrial residues. I: sugarcane bagasse. Bioresour Technol 74:69-80. https://doi.org/10.1016/S0960 -8524(99)00142-X

Pijls LT, Timmer AA, Wolde-Gebriel Z, West CE (1995) Cultivation, preparation and consumption of ensete (Ensete ventricosum) in Ethiopia. J Sci Food Agric 67:1-11. https://doi.org/10.1002/ jsfa. 2740670102

Preethu D, Bhanu Prakash B, Srinivasamurthy C, Vasanthi B (2007) Maturity indices as an index to evaluate the quality of compost of coffee waste blended with other organic wastes. In: Proceeding of international conference on sustainable solid waste management, Chennai, India, Citeseer, pp 270-275

Ryckeboer J, Mergaert J, Vaes K, Klammer S, De Clercq D, Coosemans J, Insam H, Swings J (2003) A survey of bacteria and fungi occurring during composting and self-heating processes. Ann Microbiol 53:349-410

Salomone R (2003) Life cycle assessment applied to coffee production: investigating environmental impacts to aid decision making for improvements at company level. J Food Agric Environ 1:295-300

Sánchez-Monedero M, Roig A, Paredes C, Bernal M (2001) Nitrogen transformation during organic waste composting by the Rutgers system and its effects on $\mathrm{pH}, \mathrm{EC}$ and maturity of the composting mixtures. Bioresour Technol 78:301-308. https://doi.org/10.1016/ S0960-8524(01)00031-1

Shemekite F, Gómez-Brandón M, Franke-Whittle IH, Praehauser B, Insam H, Assefa F (2014) Coffee husk composting: an investigation of the process using molecular and non-molecular tools. Waste Manag 34:642-652. https://doi.org/10.1016/j.wasma n.2013.11.010

Tack F (2013) Soil chemistry lecture notes. Ghent university, Faculty of Bioscience Engineering, Department of Applied Analytical and Physical Chemistry, Ghent

Tiquia S, Tam N, Hodgkiss I (1998) Changes in chemical properties during composting of spent pig litter at different moisture contents. Agric Ecosyst Environ 67:79-89. https://doi.org/10.1016/ S0167-8809(97)00132-1

Tirado SM (2008) Effects of turning frequency, pile size and season on physical, chemical and biological properties during composting of dairy manure/sawdust $(\mathrm{dm}+\mathrm{s})$. Master's thesis of The Ohio State University, pp 1-138

TMECC (2002) Test methods for the examination of composting and compost (TMECC), U.S. composting council, Bethesda, MD 436 
USSLS (1954) United States salinity laboratory staff (USSLS), diagnosis and improvement of saline and alkali soils. US Department of Agriculture (USDA) Handbook 60, p 160

Van Reeuwijk L (1993) Procedures for soil analysis. International Soil Reference and Information Centre (ISRIC), Wageningen

Varma VS, Kalamdhad AS (2013) Composting of municipal solid waste (MSW) mixed with cattle manure. Int J Environ Sci 3(6):2068-2079. https://doi.org/10.6088/ijes.2013030600025

Wang P, Changa C, Watson M, Dick W, Chen Y, Hoitink HA (2004) Maturity indices for composted dairy and pig manures. Soil Biol Biochem 36:767-776. https://doi.org/10.1016/j.soilb io.2003.12.012

Wiersum K, Gole T, Gatzweiler F, Volkmann J, Bognetteau E, Wirtu O (2008) Certification of wild coffee in Ethiopia: experiences and challenges. Forest Tree Livelihood 18:9-21. https://doi. org/10.1080/14728028.2008.9752614
Yusuf M (2008) Composting of khat and related materials as solid waste management option in Awaday town. M.Sc. Thesis, Addis Ababa University, Faculty of Technology, Chemical Engineering. Addis Ababa, Ethiopia, pp 1-56

Zoca SM, Penn CJ, Rosolem CA, Alves AR, Neto LO, Martins MM (2014) Coffee processing residues as a soil potassium amendment. Int J Recycl Org Waste Agric 3:155-165. https://doi.org/10.1007/ s40093-014-0078-7

Zucconi F, Pera A, Forte M, De Bertoldi M (1981) Evaluating toxicity of immature compost. BioCycle (USA) 22(2):54-57

Publisher's Note Springer Nature remains neutral with regard to jurisdictional claims in published maps and institutional affiliations. 